\title{
Ethics Surrounding Human Embryonic Stem Cell Research
}

\author{
Ogar JN1 ${ }^{1}$ and Bassey SA2* \\ ${ }^{1}$ Department of Philosophy, University of Calabar, Nigeria \\ ${ }^{2}$ University of Calabar, Nigeria
}

*Corresponding author: Samuel Akpan Bassey, University of Calabar, Calabar, Cross
Research article
Volume 2 Issue 1
Received Date: May 28, 2019
Published Date: October 24, 2019
DOI: $10.23880 /$ abca- 16000108

River, 540242, Nigeria, Tel: 7060721631; Email: samuelbassey15@yahoo.com

\section{Abstract}

Since their discovery in the early 1990's, Stem Cell have brought the promise of evolutionary and significant scientific and medical research with the prospect that possessed the possibility of radically improving treatments for a host of diseases such as Alzheimer's, Parkinson's disease, various cancers and other diseases that currently render patients and scientists helpless to combat. With the advent of medical and scientific research, comes the inevitable emergence of the controversy that has accompanied every major scientific and medical advancement. The use of Stem Cell is no different. Those who seek to curtail the use of certain stem cell lines, revert to the argument that has defied many medical debates over the previous decades. The argument, the destruction of human life to create life, is the stalwart philosophical point that all anti-stem cell advocates attempt to make. The purpose of this discussion is to engage in an analysis of the various aspects of the ethical debate concerning the use of stem cells in medical research.

Keywords: Ethics; Stem Cells; Medical Research; Human Embryo

\section{Introduction}

Stem Cells have been at the center of the scientific research paradigm in terms of developing innovative treatments that could revolutionize the current course of medical care [1]. This argument, the destruction of human life to create life, is the stalwart philosophical point that all anti-stem cell advocates attempt to make. These individuals equate the use of stem cells as akin to murder, the same vantage point that the anti-abortion interest groups use to persuade others. The process is the taking of innocent human life [2]. Those who seek to curtail the use of certain stem cell lines, revert to the argument that has defined many medical centric debates over the previous decades. Conversely, those who purport the use of stem cells often find themselves in agreement with scientific evidence that demonstrates how potent stem cells are in terms of treating previously untreatable diseases. Humans, for the most part, seek to minimize pain and maximize pleasure. This dichotomy can be expressed in medical terms as well. Individuals are willing to involve themselves in various treatments that can prolong their lives or possibly reverse their condition. To this end, public opinion generally comes down in favor of stem cells research.

\section{Human Embryonic Stem Cell}

Stem cells are akin to "blank slates" in terms of their genetic development and principles. It possesses two unique qualities that separate them from other cells in the 
human body [3] First, Stem Cells are undifferentiated at their outset, and this means that a stem cell has the ability to develop into any cell type in the body. A stem cell can be produced in the red bone marrow and then be placed into a petri dish with cardiac cells. Eventually, the stem cell will adapt the properties of those surrounding cardiac cells and develop into another cardiac cell-taking with it all the qualities and characteristics of the cardiac cell they are introduced to. This differentiation principle allows stem cells to repair damaged tissues and organ systems. There have been many studies that demonstrate infusion of stem cell into damaged muscle tissue following trauma can increase the likelihood of a patient having a positive recovery, minimizing damage to internal organs or tissues. This principle is highly valuable to scientists seeking to harness this differentiation principle to direct stem cell in their quest to cure certain diseases [4]. There are two distinct types of stem cell that researchers have used; Embryonic and Adult. The more potent stem cell lines that are used in medical research are derived from frozen human embryos, this Human Embryonic Stem Cell possess the greatest capacity to develop and foster immense possibilities in dealing with diseases. These stem cells are derived from those embryos that have been frozen and are waiting for fertilization from a male gamete. However, there are some instances in which these embryonic stem cells are not fertilized; therefore they are set to be discarded. Rather than have these embryos destroyed, they are used for scientific research to harvest their DNA and used in clinical treatments or academic research to investigate the impact of certain proposed treatments.

In recent years, scientists have been able to identify highly specialized conditions that allow a cell to be "reprogrammed" and revert back to its stem cell state; allowing it to exhibit the main principles of a stem celldifferentiation and tissue repair. These cells are referred to as "Induced Pluripotent Stem Cells" or (IPSC's). All three categories of stem cells: embryonic, adult and IPSC all possess the potential to radically alter the course of modern medicine and unlock the full impact of cell-based regenerative therapies to treat diseases such as diabetes, myocardial infarctions along with Alzheimer's and Parkinson's. Despite the inherent similarities between these various cell lines, there are differences that must be addressed.

The first difference is that each cell line inherently contains various levels of differentiation abilities. For example, Human Embryonic Stem Cells (hESC's) possess the highest level of differentiated ability in that they can be programmed to form any type of cell in the human body. Adult stem cells exhibit a more limited capacity for differentiation. Adult stem cells are limited to differentiating into additional cells from their tissue of origin. Specifically, an adult stem cell from a calf muscle cannot be introduced into the spinal column in order to regenerate damaged nerve tissue. Another critical difference between the two cell lines involves their generation.

Embryonic stem cells are more readily produced in culture. Adult stem cells, in contrast, are rarely found in mature tissue, therefore the process of isolating these cells is increasingly difficult. A related distinction is the ability of tissues derived from these cell lines to be rejected after transplantation. Currently, there is little data involving the tissues derived from Human Embryonic Stem Cells given that the Food and Drug Administration has only recently given approval to allow human testing in Phase-1 clinical trials that involve transplanting tissues generated from Human Embryonic Stem Cells [5]. Conversely, there is ample data to suggest that those tissues created from Adult stem cells are less likely to be rejected during transplantation. The science behind this principle is relatively straightforward; the patient's own cells are utilized in creating this newly formed tissue, therefore the incidents rates and probability of the patient's own T-Cells and B-Cells creating a histological reaction to "self" is increasingly unlikely.

IPSC's or "Induced Pluripotent Stem Cells" are the latest stem cells to be developed by research scientists. As defined earlier, these stem cells are not an individual stem cell line, like Embryonic or Adult, they are more akin to a "sub-division". These are cells that have been genetically reprogrammed through a variety of recombinant DNA and RNA technologies that have allowed these cells to revert to their stem cell phase, hence the word "Induced"these cells are "induced" into becoming stem cells. Two types of IPSC's were developed. Each of these cell lines exhibited qualities important to the foundation of pluripotent stem cells. Bot mouse and human IPSC's were able to form tumor necrosing cells, exhibit numerous cell markers and differentiate into a variety of tissues once injected into mice. Although these stem cells are only a few years old, they possess unlimited potential in terms of clinical research. Specifically, scientists are focusing their potential uses in transplant medicine in order to significantly reduce the level of both infections and overall organ rejection in organ transplant surgery. 
The potentials for using stem cells is of vast clinical and medical importance. These cells could allow scientists to learn what occurs at the cellular and molecular levels of human development and use this information to identify certain molecular pathways that contribute to a variety of conditions. Furthermore, using these stem cells could also allow scientists to discover the genes that are triggered in response to certain cellular conditions that cause rapid, unchecked cell growth or irregular cellular patterns. Additionally, using stem cells to discover certain genetic conditions will lend immense amount of information to the scientists and afford researchers the opportunity to enhance their understanding of various disorders caused by genetics.

\section{Issues Raised about Stem Cells}

However, despite these growing potentials, there are obstacles associated with the utilization of these cell lines in pursuit of medical advancement. The use of stem cells comes attached with a variety of legal, ethical, moral and philosophical issues. The remainder of this discussion will focus on these issues. Those who assert that killing human embryos is morally reprehensible usually assert the maxim that all individuals were once embryos, deserving of all the respect that other human beings are accustomed to. This argument blends the ethical, religious and philosophical elements of the concept of the commencement of human life. This maxim has two main branches:

$>$ The embryo is the earliest stage of development in the existence of a human being and

$>$ Human beings have the same moral standing at all stages of growth and development, including the embryonic stage [6].

These two branches are inherently philosophical in nature in that it portends to make distinctions regarding human nature. These maxims seem incompatible with the moral reasons used to justify treating individuals in varying manners dependent on their nature. If an individual was once an embryo it would logically flow that that individual's nature was different. Therefore, it is permissible to treat you in a manner that would be inappropriate as this individual became older. It appears implausible to assume that radical changes in an individual's nature can never affect that individual's moral status.

The major counterpoint to the religiosity of the antistem cell research argument is to posit the question "Are six-day old embryos human organisms?" [7]. Although modern science has not clarified or lent any assistance in determining if a six day embryo is a human being, there is certainly room to create reasonable doubt. There are two competing attitudes regarding what happens once conception occurs. The first constructs assumes that subsequent cell division is but the first steps in the life span of a single individual possessing differentiating characteristics that will make up their essential self and allow the individual to develop into a rational adult. The second construct does not treat the combination of the female and male gamete as a human organism [8].

With respect to the first premise, although it is true that all the cells are in a single unit- they are held together by a singly cellular membrane it is difficult to determine what makes all these various cells parts of an individual. This logical premise leads yet to another question, or requirement, in order to determine what makes these cells a single human individual, there must be the determination about what, exactly, a human organism is-a "first principles" approach to examining this question. Human organisms are entities with human genes that compose living organs that function together in agreement; however, these organs in and of themselves do not constitute living organisms [9].

The second construct regarding what occurs after the combination of male and female gametes holds that this combination and the inevitable delegation of cells does not constitute a human organism. According to this philosophical premise, once this single cell begins to divide, only the constituent make components of the cells remain [10]. When the first cell divides, it ceases to exist, although its offspring is two daughter cells. Likewise, when these cells divide they cease to exist leaving in its wake the offspring cells. Therefore there is not a single individual that remains throughout the transformation. Only when there is a substantial differentiation in cellular function, position and structure that the claim about integrating components of an organismic structure being present. Scientifically, this type of distinctive presentation is not present until roughly two weeks after fertilization it seems logical this is the period where human beings are said to exist.

Those who seek to assert that the very first levels of embryonic development constitute a valid human life, worthy of the highest levels of protection bear a foreseeable objection that lead to yet another philosophical question that must be addressed when considering the ethical issues that would have to be resolved to allow embryonic stem cell research [10]. The issue of cellular specialization appears to be a critical 


\section{Annals of Bioethics \& Clinical Applications}

component of those that seek to say the embryo is a human life. However, the question that must be answered is, at the time these individuals claim an embryo represents a human life; does the embryo at this time represent a higher order of life? This question ventures from the purely biological to the metaphysical [11].

If the minimal degree of cellular interaction is to be determined as the beginning of human life, then brain death should not be considered both the legal, ethical and biological standard of when a person cease to live. Brain death is compatible with the essential premise of cellbased interaction between neural cells and other tissues and cells within the human body [12]. However, modern science and for that matter all relevant practicality has defined this state as a state wherein individuals have ceased to live. In a more philosophical sense, they have lost all essential self-qualities and have simply become an amalgamation of different cells tissues and organ systems- in almost all cases; those individuals in this predicament are sustained by artificial means, i.e. life support. Even the most ardent defender of the rights of an embryo would be hard pressed to define an individual possessing the same level of cellular interactions and operations as that of a six day embryo as a viable, living human being [13].

The arguments underlying the need for human embryonic stem cell research incorporate various philosophical and metaphysical principles to establish the maxim that embryos are not individuals based on the logical premise that although the embryo is a collection of cells working in concert at a level higher than they would exhibit in singularity; their concerted effort does not lend itself to define the embryo as a "higher order of life"-a human being, therefore, this leads to the logical conclusion that if the embryo is not an individual by not being a "higher order of life" then the embryo is not deserving of any additional protection or the equivalent protections afforded to traditional human beings [14].

The arguments against embryonic stem cell research are deeply rooted in ethical, moral and religious grounds and theories. All forming an overarching construct that will serve to bolster their premise that embryos represent the most innocent of human life and needed to be afforded the maximum amount of protection under the law.

The arguments against embryonic stem cell research begin from the proposition that the embryo is undoubtedly the most complex entity known to man. The argument acknowledges that the embryo does not even closely resemble in the slightest bit the makings of a human being, in the traditional sense. However, the fact that all human beings start as embryos brings into context the gravity of each and every individuals origins and the need to value those origins as sacred human life. The embryo commands a certain level of respect and it is imperative that this respect is maintained.

The main philosophical tenant of this argument is the fertilization of a female gamete by a male gamete represents the union of a man and a woman to foster the development of a human life [15]. Therefore, the embryo is a human life in its most basic of forms. According to this purview the embryo is not just a collection of cells but rather a cohesive unit working together in concert to perform those vital functions that render human life in existence [16]. This argument seeks to remedy the position taken by those who argue in favor of stem cell research regarding the distinguishing characteristics between a fully developed human being and a gesticulation phase embryo [15]. Accordingly, an individual is an individual regardless of the stages of development.

All humans are afforded the basic protections of their morality and dignity regardless of their stage of development or level of distinguishing characteristics. The more serious aspects of this logical construct deals with individuality, potentiality and "special respect". Those who seek to impart a moral supremacy to the embryo counter the " 14 " day mark by asserting that the innate genetic conditions that quintessentially define what it means to be a human being are present at the first moment of conception [17]. Therefore, nothing happens after that bestows upon the embryo the degree of "humanness" necessary to trigger the moral protection of a human embryo. In deed those taking this line of reasoning find agreement in the ancient text of Aristotle that discusses the "handedness" of a thing, in that the essential qualities are present even if a thing lacks traditional structures and qualities.

The morality and ethical constructs that are present within the logical premises that form the underlying foundation of the arguments against stem cell research inevitably circle back to the concept that the aura surrounding the embryo is one of intense mystery. The mere existence of the embryo demonstrates the very essence of human history-given that all individuals started out as a fertilized egg; adding the rubric of preserving this state of being through enhanced moral 
and ethical protections renders their use in scientific research nearly impossible. This maxim flows into the overtly religious aspect of the argument, the aspect of protecting the weakest among you; similar to Jesus' words "When you did so for the least amongst you, you have done so for me" [18].

This religious connotation is firmly demonstrated in the arguments used by those individuals and groups seeking to curtail stem cell research. The very existence of the human embryo and its use in scientific research, according to this group, goes to the very heart of what it means to treat all individuals with the same level of equality-although one could very easily argue that the turbulent history of the United States has certainly contained some contradictory events to this very fundamental precept. For those seeking to limit the use of embryonic stem cells in laboratories, the issue boils down to two simple absolutes: the embryo is the weakest form of humanity and society must maintain consistency with its moral justifications to ensure that all individuals regardless of background or stage of development are entitled to equal protections under the law and morality [19]. These truths lead to an examination of the societal aspects of this argument.

Those who argue the moral and religious connotations in relation to embryonic stem cell research hold that this form of scientific inquiry represents the crossing of several moral and ethical boundaries. Using embryonic stem cells for the sole purpose of their destruction creates a sort of instrumentality of human life [20]. This argument makes the distinction that those embryos that were set for destruction did not lose their moral authority if those embryos were used for medical research [21]. However, the moral justification for limiting stem cell research calls out those cells that are "programmed" to revert to their stem cell state and are in turn used for the sole purpose of being destroyed. These "re-programmed" cells, referred to as IPSC's lose all moral equivalencies and therefore should not be generated for the singular purpose of destruction [20].

When this logical paradigm is viewed through the perspective of the fate of the embryo itself, the distinction-morally speaking-between an embryo destined for destruction and creating a stem cell through inducement may be insignificant. However, when viewing this tension through the lens of how it affects the very moral fabric of our society the issue becomes more complex. Those who portend the embryo is a representation of the earliest forms of humanity contend that once using embryos for the singular purpose of genetic and medical research begins it will be increasingly difficult to arrive at a natural stopping point [22]. This, according to this logic, would lead to the very real possibility of further moral hazards being encountered, excused and accepted. The logical conclusion of this argument is that a society that readily excuses the destruction of unborn fetus' within the second and third trimester will not be morally outraged by the deliberate use of an embryo for clinical research into genetic conditions that spur the onset of a specific disease [23].

At their core, those arguing the moral relativism against stem cell research find themselves asserting the doctrine of "personhood and the right to life". This was a maxim first expressed in the Supreme Court's decision in the landmark case Roe v. Wade. In this opinion, the court did concede some ground to those in the moral camp by asserting that the embryo did on some level represent a degree of humanity with the inherent characteristics and qualities other humans have and enjoy. The court even references the concept of "potential people" and states that there is something not just imprudent but also immoral about the willful and wanton destruction of "potential people"; however, the court went on to say that this right does not trump the woman's right to terminate the pregnancy. This bellies the point that the US Supreme Court on some level did acknowledge that "potential people" do exist and are deserving of certain rights. Therefore those that claim that stem cell research is predicated on a disregard for the basic of all human rights, the right to life finds comfort in a legal opinion that at its logical conclusion opted for the right of the human over the "potential person".

Within the ideological construct of opposing stem cell research because it would destroy life there is a growing subset of those who feel it is appropriate to conduct research on aborted fetuses. The underlying logic of this premise is that an aborted fetus is already dead and that if modern science and engage in nuclear transfusion to clone embryos then they would be capable of utilizing an already deceased fetus to engage in stem cell research. If the expansion of destructive research on IVF embryos and the initiation of cloning for research are allowed to go ahead, this will generate further moral problems concerning the issue of complicity in these activities [24]. It is morally wrong not only to destroy human beings, but also to commission or authorize their destruction. Cloning and stem cell research create serious problems of conscience for doctors, patients, researchers and those asked to donate material to produce embryos for research 


\section{Annals of Bioethics \& Clinical Applications}

[25]. For example, a patient who supplies a cell for the purpose of creating a clone would be intending the destruction of the clone for the sake of harvesting its cells.

Complicity problems are not limited to cases where one intends the wrongdoing of others. Even those who do not intend an act of injustice can act wrongly themselves by giving the impression they condone it, if what they do is closely linked to such an act [26]. Thus a patient might be acting wrongly if he or she accepted a stem cell treatment - even one which did not itself destroy embryos-if that treatment had been developed by means of the destruction of embryos.

If the only treatment developed for a serious medical condition is one that involves, or has involved, the creation and destruction of embryos, this will condemn conscientious physicians and patients to endure a cruel trial. Unless they act against their conscience-and do what they consider inhuman and barbaric-patients will suffer without hope of treatment and doctors will be unable to offer any alternative [27]. This situation would be intolerable. Embryonic stem cell research is morally problematic because an evil means is used to secure a good end. In essence, accepting embryonic stem cells obtained through elective abortion makes one an accomplice to a crime after the fact. Unlike adult organ donations, the death of the embryo is intentionally caused. This is hardly the same as when organs are recovered from someone killed in a tragic accident. Consider the case of a hospital that becomes the beneficiary of a gang of killers who supply it with fresh cadavers. Surely one could question the moral appropriateness of the hospital's continuing cooperation with the suppliers

\section{Conclusion}

Stem cell research has been at the forefront of biotechnological advances because of the potential curative uses of the cells. Research into stem cells and how they divide can help provide answers about how cells divide and ultimately teach researchers how improper cell division occurs in cancer and birth defects. Once the scientists learn the process of cell division in these, the hope is that they can then develop cures. Research into stem cells can lead to improvements in the efficiency of drugs for treatment of a variety of illnesses. In addition, many researchers believe that stem cell research can help them develop cures for diabetes, cardiovascular and other diseases by helping scientists develop processes for creating new body organs or repairing existing body organs that have become diseased. Stem cells are cells that have the ability to divide indefinitely and to differentiate into any type of cell, including organ, skin or any other type of cells. Stem cells are created as part of the fertilized egg or zygote that is created in the first few days after an egg is fertilized. As the zygote divides into more cells, it becomes an embryo. Human stem cells are generally isolated from either the embryo (known as embryonic stem cells) or from fetal tissue (known as embryonic germ cells).

The "human" status of an embryo, if any, is complicated and arguably non-existent under the law. Zygotes are the first combination of cells that grow into the embryo, shortly after fertilization. An embryo develops after the initial fertilization and from the zygotes. At the point of fertilization, the zygote (and thus the embryo) has the potential to become a "born" human being. It possesses all the chromosomes necessary to become a distinct, unique human being, although it is not sentient. Embryonic stem cells grow after the initial fertilization and before the embryonic cells differentiate into brain cells, tissue cells, and other specific cells of the body. As noted above, the law treats the stem cells as property (as noted above) that can be patented. Zygotes are also treated as property; the next question is the law's treatment of embryos: are they persons or property?

The ethical issues are as thorny and complicated as the legal issues. There is also no final arbiter to determine how the moral issue should be resolved. The legal analysis at least demonstrated the courts' stance on the human rights of embryos. From a moral perspective, if the stem cells are merely cells, i.e. property, and the stem cells are not persons, then the ethical issue is different than if the stem cells, zygotes and/or embryos are persons. A brief summary of key ethical theories follows.

Immanuel Kant's key moral principle is the concept of a good will. The good will exists beyond intelligence, power, wealth, and happiness. Although intelligence, power, wealth, and happiness can be evidence of a good will, these qualities are not intrinsically good will because they can be perverted [28]. It is the good "character" which helps to determine whether someone's actions are moral or not. Duty is the objective manifestation of good will and an action is moral if it is done because of this duty, regardless of consequences. The ultimate good in Kant's eyes is the individual's decision to act consistently with the principles that help to obtain the ultimate goal, a good will, which is valuable in and of it. An important maxim for Kant's philosophy is the categorical imperative: 


\section{Annals of Bioethics \& Clinical Applications}

"Act so that you treat humanity, whether in your own person or in that of another, always as an end and never as a means only."

How does Kant's analysis apply here? The key would be to determine whether there were any duties to stem cells, zygotes or embryos. One could argue, although Kant seemed to support scientific inquiry, that whether stem cell research was valid depended on whether zygotes would be treated as human. Since they are parts of nature, perhaps one could argue that application of a Kantian analysis results in a prohibition against treatment of zygotes as a means to an end, rather than as human beings. This would be independent of a determination of whether the zygotes or embryos were human or not. One could also use Kant's analysis to support a position that the duties would be to those who are currently existing, e.g. that the duty to permit individuals to procreate (or not) is a higher duty.

Utilitarian philosophy requires analyzing an action or a principle to determine whether that action maximizes the good for society. Jeremy Bentham and his student, John Stuart Mill, defined the principle of utility as relating to the issue of maximizing the pleasure or good for the individual and thus for society. The principle of utility focuses on determining whether an action is moral or right based on the consequences.

As Bentham explained, "By utility is meant that property in any object, whereby it tends to produce benefits, advantage, pleasure, good or happiness or to prevent the happening of mischief, pain, evil or unhappiness to the party whose interest is considered: if that party be the community in general, then the happiness of the community; if a particular individual, then the happiness of that individual". Under this philosophy, actions or concepts that will bring pleasure may be instrumentally good, i.e. because they help to accomplish the ultimate good-pleasure. There are no true intrinsic goods except the maximum of happiness.

\section{References}

1. Bellomo M (2006) The Stem Cell Divide: The Facts, the Fiction, and the Fear Driving the Greatest Scientific, Political, and Religious Debate of Our Time. American Management Association, New York pp: 272.

2. Bevington LK, Bohlin RC, Stewart GP, Kilner JF, Hook CC (2004) Basic Questions on Genetics, Stem Cell
Research and Cloning: Are These Technologies Okay to Use? Grand Rapids: Kregel.

3. Carrier E, Gracy L (2004) 100 Questions \& Answers about Bone Marrow and Stem Cell Transplantation. In: Jones, Bartlett, et al. (Eds.), Jones \& Bartlett Learning $1^{\text {st }}(E d n$.$) , Sudbury.$

4. Levine AD (2011) Policy uncertainty and the conduct of stem cell research. Cell Stem Cell 8(2): 132-135.

5. Fink DW (2013) Human Embryonic Stem Cells and the Food and Drug Administration. Human Embryonic Stem Cells pp: 323-343.

6. Diana D, Daniel P (2008) Sex, Science, and Stem Cells: Inside the Right Wing Assault on Reason. Guilford, CT: The Lyons Press.

7. Rabbany SY, Rafii S (2007) Cell of Cells: The Global Race to Capture and Control the Stem Cell. J Cinc Invest 117(9): 2349.

8. Lauri FS, Marcovitz H (2009) Is Stem Cell Research Necessary? Reference Point Press pp: 96.

9. Ronald GM (2001) The Human Embryo Research Debates: Bioethics in the Vortex of Controversy. Oxford University Press, New York pp: 231.

10. Eve H, Daley G (2007) Stem Cell Wars: Inside Stories from the Frontlines. New York: Palgrave Macmillan.

11. Holland S, Lebacqz K, Zolotheds L (2001) The Human Embryonic Stem Cell Debate: Science, Ethics, and Public Policy. Basic Bioethics.

12. James HM, Almeder RF (2004) Stem Cell Research. Totowa, NJ: Humana.

13. Juengst E, Fossel M (2000) The Ethics of Embryonic Stem Cells: Now and Forever, Cells Without End. JAMA 284(24): 3180-3184.

14. Kass LR (2002) Life, Liberty, and the Defense of Dignity: The Challenge for Bioethics. San Francisco: Encounter. The Quarterly Review of Biology 78(3): 343.

15. Russell K, Munzer SR (2009) Stem Cell Century: Law and Policy for a Breakthrough Technology. Yale University Press, New Haven, Journal of Health \& Biomedical Law 1: 131-149. 
16. Alan M (2007) Stem Cell Research and Cloning. Chelsea House, New York.

17. Mulkay M (1997) The Embryo Research Debate: Science and the Politics of Reproduction. Cambridge: Cambridge University Press pp: 228.

18. Rolston H (1996) The Bible and Ecology. Interpretation: A Journal of Bible and Theology 50(1): 16-26.

19. Joseph P (2006) Stem Cell Research: Medical Applications and Ethical Controversy. New York pp: 178.

20. Ted P (2010) Sacred Cells? Why Christians Should Support Stem Cell Research. Rowman \& Littlefield 17(2): 179-181.

21. Peters (2007) The Stem Cell Debate. Fortress, Minneapolis.

22. John RA (2002) Science and Society: Human Embryonic Stem Cell Research: Ethical and Legal Issues. Nature Reviews Genetics 2: 74-78.
23. Michael R, Christopher AP (2003) The Stem Cell Controversy: Debating the Issues. $2^{\text {nd }}$ (Edn.), pp: $347-$ 348.

24. Stanley SB (2002) Becoming Immortal: Combining Cloning and Stem-cell Therapy. Albany: State University of New York Press 77(4): 438-490.

25. Snow NE (2003) Stem Cell Research: New Frontiers in Science and Ethics. In: University of Notre Dame Press pp: 232.

26. Waters B, Cole Turner R (2003) God and the Embryo: Religious Voices on Stem Cells and Cloning. DC: Georgetown University Press, Washington pp: 228.

27. Wertz DC (2002) Embryo and Stem Cell Research in the USA: A Political History. Trends Mol Med 8(3): 143-146.

28. Christopher PS, Clarke RB, Wilson J, Renehen AG (2006) Tissue Stem Cells. Informa Healthcare, New York. 